\title{
SYNTHESIS AND IN VITRO ANTIBACTERIAL ACTIVITY OF FOUR NOVEL PLEUROMUTILIN DERIVATIVES
}

\author{
YOUZHI TANG*\#, JIAN LUO", XIAOJIE CHEN, BO WANG, XIANGGUANG SHEN, JIANHUA LIU* \\ Guangdong Provincial Key Laboratory of Veterinary Pharmaceutics Development and Safety Evaluation, \\ College of Veterinary Medicine, South China Agricultural University, Guangzhou 510642, China
}

(Received: May 4, 2012 - Accepted: October 4, 2012)

\begin{abstract}
Four novel pleuromutilin derivatives with butyl amine group in the C-14 side-chain were designed, synthesized and confirmed by FT-IR, ${ }^{1} \mathrm{H}-\mathrm{NMR}$ and HRMS. The results of antibacterial activity showed that the antibacterial activity of pleuromutilin derivatives could be affected by the steric hindrance of their C-14 side-chain.
\end{abstract}

Key words: pleuromutilin derivatives, antibacterial, Staphylococcus aureus.

\section{INTRODUCTION}

Due to the dramatic increasing of antibiotic resistance among pathogenic bacterial strains, research efforts are focusing on new antibiotics that have unique modes of action and activity against resistant organisms. During the past 25 years, the number of antibiotics which have been approved by the Food and Drug Administration (FDA) decreased annually. ${ }^{1}$ Actually, after the discovery of sulphonamide antibiotics in the 1930s and penicillin in the 1940s, there were only three novel classes of antibacterials, the topical antibiotic mupirocin, the oxazolidinones (linezolid) and the cyclic lipopeptides (daptomycin) which had entered the market. ${ }^{2}$ This fact, as well as the demands of new antibiotics discovery and development, have led to the reassessment of previously discovered antibacterial agents which have not been used in humans such as pleuromutilin (1, Figure 1$).^{3}$

Pleuromutilin, a natural antibiotic with modest antibacterial activity, was first isolated in 1951 from the basidiomycetes Pleurotus mutilis and $P$. passeckerianus. ${ }^{4}$ Pleuromutilin derivatives selectively inhibit bacterial protein synthesis through binding to the ribosomal peptidyl transferase center (PTC). ${ }^{5}$ This unique mode of action of pleuromutilin derivatives makes them to rarely exhibit target-specific cross-resistance to other antibacterial agents. Two pleuromutilin derivatives, timamulin (2, Figure 1) and valnemulin (3, Figure 1 ), have been used in veterinary medicine to treat serious infections in pigs and poultry. Unfortunately, azamulin (4, Figure 1), the first human-used derivative of pleuromutilin, failed in Phase I clinical trials for its rapid metabolism and subsequent excretion in vivo. ${ }^{6}$ The semi-synthetic pleuromutilin derivative retapamulin (5, Figure 1) was approved in 2007 by the FDA for the topical treatment of uncomplicated skin and skin structure infections (SSSIs). Thus, the pleuromutilin derivatives have regained interest as potential antibacterial agents for human use. In addition to the structural modification of pleuromutilin, more and more methods have also been reported to synthesize the molecular framework of pleuromutilin. ${ }^{7-9}$
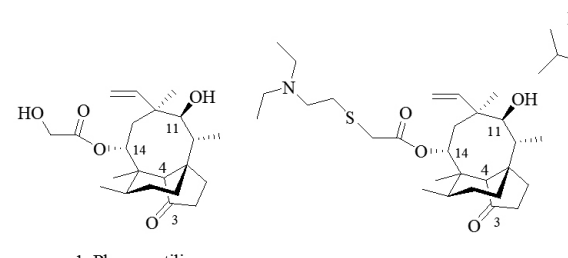

2. Tiamulin

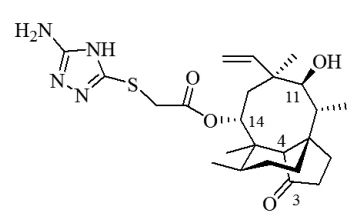

4. Azamulin

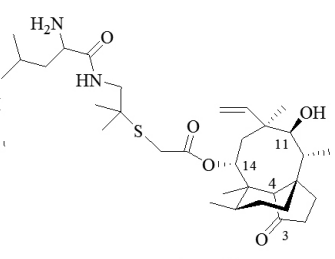

3. Valnemulin

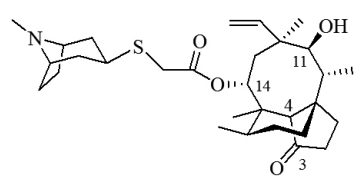

5. Retapamulin
In order to develop new analogues with potent antibacterial activity, a large number of pleuromutilin derivatives have been investigated. The most successful group is semi-synthetic pleuromutilins with different substituent groups on the C-14 ester side-chain of pleuromutilin. ${ }^{10}$ The C-14 sulfanylacetate pleuromutilin derivatives of this group, including tiamulin, valnemulin, azamulin and retapamulin, possess a broad-spectrum and excellent antibacterial activity against various clinically relevant bacterial strains. ${ }^{11,12}$ However, these C-14 sulfanyl-acetate pleuromutilin derivatives' oral bioavailability is usually limited because of their poor solubility in water. To overcome this problem, Hirokawa and coworkers designed and synthesized a large number of C-14 sulfanyl-acetate pleuromutilin derivatives in 2008 and 2009. Several promising compounds were got from C-14 sulfanyl-acetate pleuromutilin derivatives. ${ }^{13,14}$ But the C-14 acyl-carbamate derivatives, which include SB-571519 (6, Figure 2) and SB-222734 (7, Figure 2), possessed more metabolic stability than other types of pleuromutilin derivatives. Such derivatives seemed more suitable for oral administration. ${ }^{6,12}$

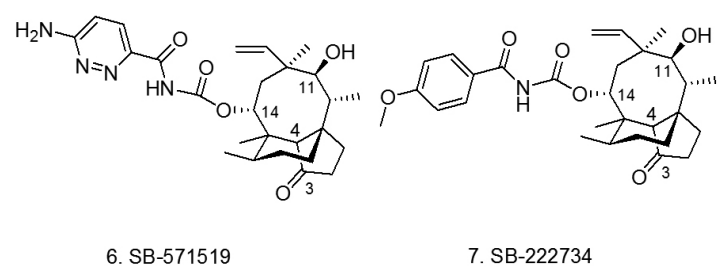

Figure 2. Chemical structures of compounds 6 and 7

Considering amines are usually as important functional groups to many drugs, four novel pleuromutilin derivatives containing butyl amine in their C-14 side-chain are described in this article, and the antibacterial activities of these four derivatives against five sensitive strains were evaluated by a standard procedure in vitro.

\section{METHODS AND MATERIALS}

\section{Materials}

Pleuromutilin ( $>90 \%$ pure) was obtained from Great Enjoyhood Biochemical Co Ltd (Daying, China). The other reagents were all of analytical grade and purchased from Guangzhou Chemical Reagent Factory (Guangzhou, China). ${ }^{1} \mathrm{H}-\mathrm{NMR}$ spectra were measured on Bruker AV-300 or Bruker AV600 spectrometer in $\mathrm{CDCl}_{3}$. Chemical shift values $(\delta)$ were given in p.p.m. and tetramethylsilane was used as internal standard. Fourier transform infrared (FTIR) were obtained with a Nicolet 6700 Research FTIR spectrometer using $\mathrm{KBr}$ pellets. Mass spectra were recorded with Agilent 6430 and LTQ-orbitrap mass spectrometer (Thermo Fisher) using the electro spray ionization (ESI) method.

Methods

The synthetic route was shown in Scheme 1.

Figure 1. Chemical structures of compounds 1 5 


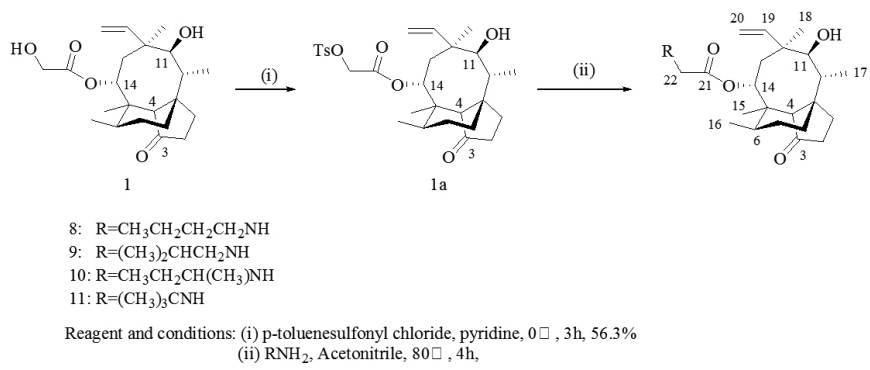

Scheme 1. The synthetic route of pleutromutilin derivatives $8 \sim 11$

\section{2-O-tosylpleuromutilin (1a)}

A solution of pleuromutilin $1(4.8 \mathrm{~g}, 12.69 \mathrm{mmol})$ in pyridine $(8.6 \mathrm{~mL})$ was stirred at $0^{\circ} \mathrm{C}$ in a three-necked round bottom flask, and $p$-toluenesulfonyl chloride $(3.6 \mathrm{~g}, 18.87 \mathrm{mmol})$ was added. The solution was stirred at $0^{\circ} \mathrm{C}$ for $3 \mathrm{~h}$. $\mathrm{CHCl}_{3}(50 \mathrm{~mL})$ and Ice-cold water $(50 \mathrm{~mL})$ were added to the solution. The organic phase was washed with a $2 \mathrm{M}$ aqueous solution of $\mathrm{H}_{2} \mathrm{SO}_{4}$, a saturated aqueous solution of $\mathrm{NaHCO}_{3}$ and water, respectively. Then the organic phase was dried with anhydrous $\mathrm{Na}_{2} \mathrm{SO}_{4}$ for $2 \mathrm{~h}$ and evaporated in vacuum. The residue was precipitated from isopropanol to give a white solid (3.8 g, 56.3\%), ${ }_{5}^{5} \mathrm{MS}(\mathrm{ESI}) \mathrm{m} / \mathrm{z} 555.4[\mathrm{M}+\mathrm{Na}]^{+}$.

\section{The synthetic route of pleuromutilin derivatives 8-11}

A solution of compound $1 \mathrm{a}(1.3 \mathrm{~g}, 2.4 \mathrm{mmol})$ in acetonitrile $(10 \mathrm{~mL})$ was added a solution of a butylamine ( $n$-butylamine, iso-butylamine, $( \pm)$-secbutylamine and tert-butylamine) $(1.3 \mathrm{~mL})$ in acetonitrile $(20 \mathrm{ml})$ in threenecked round bottom flask. The mixture was stirred at $80^{\circ} \mathrm{C}$ for $4 \mathrm{~h}$, followed by cooling to below $60^{\circ} \mathrm{C}$. Water $(50 \mathrm{~mL})$ was added to the solution, which was then extracted with $\mathrm{CHCl}_{3}(50 \mathrm{~mL})$. The organic phase was washed with a saturated aqueous solution of $\mathrm{NaHCO}_{3}$, water, dried $\left(\mathrm{Na}_{2} \mathrm{SO}_{4}\right)$ and concentrated under reduced pressure to give the crude product. The crude product was purified by silica gel column chromatography using petroleum ether/ethyl acetate/ethanol $(5: 1: 0.2)$ as eluent to give a pure product.

22- $\mathrm{N}$ - $n$-butylpleuromutilin (8)

Prepared according to the above general preparation of pleutromutilin derivatives 8-11. Light pink powder; yield: 53.1\%; m.p.: 55.0-57.4 ${ }^{\circ} \mathrm{C} ;{ }^{1} \mathrm{H}-\mathrm{NMR}$ spectrum $(300 \mathrm{MHz}$; d $-\mathrm{CDCl}$. TMS): $\delta(\mathrm{ppm}) 6.528(1 \mathrm{H}, \mathrm{dd}, J 11.1,17.4$ $\mathrm{H} 19), 5.797(1 \mathrm{H}, \mathrm{d}, J 8.4, \mathrm{H} 14), 5.357(1 \mathrm{H}, \mathrm{dd}, J 1.2,10.8, \mathrm{H} 20), 5.205(1 \mathrm{H}$, dd, $J 1.5,17.4, \mathrm{H} 20), 3.355(2 \mathrm{H}, \mathrm{d}, J 17.4, \mathrm{H} 22), 3.255(1 \mathrm{H}, J 17.7, \mathrm{H} 11)$ 2.856-2.487 (2H, m, $\left.\mathrm{CH}_{3} \mathrm{CH}_{2} \mathrm{CH}_{2} \mathrm{CH}_{2} \mathrm{NH}\right), 2.386-2.039$ (5H, m, H2, H4, H10, $\mathrm{H} 13), 1.807-1.471\left(9 \mathrm{H}, \mathrm{m}, \mathrm{H} 1, \mathrm{H} 6, \mathrm{H} 7, \mathrm{H} 8,11-\mathrm{OH}, \mathrm{CH}_{3} \mathrm{CH}_{2} \mathrm{CH}_{2} \mathrm{CH}_{2} \mathrm{NH}\right)$ $1.452(3 \mathrm{H}, \mathrm{s}, \mathrm{H} 15), 1.400-1.278\left(4 \mathrm{H}, \mathrm{m}, \mathrm{H} 8, \mathrm{H} 13, \mathrm{CH}_{\mathrm{CH}} \mathrm{CH}_{2} \mathrm{CH}_{2} \mathrm{NH}\right), 1.167$ $(3 \mathrm{H}, \mathrm{s}, \mathrm{H} 18), 0.932-0.870\left(6 \mathrm{H}, \mathrm{m}, \mathrm{H} 17, \mathrm{C}_{3} \mathrm{CH}_{2} \mathrm{CH}_{2} \mathrm{CH}_{2}^{2} \mathrm{NH}\right), 0.724(3 \mathrm{H}, \mathrm{d}$, $J$ 6.6, H16); IR $\left(\mathrm{KBr}, \mathrm{cm}^{-1}\right) 3448.44,2955.14,2864.59,1728.97,1637.45$, 1458.33, 1153.60, 1117.08, 1018.74; HR-MS (ESI): Calcd for $\mathrm{C}_{26} \mathrm{H}_{44} \mathrm{NO}_{4}(\mathrm{M}-$ $\left.\mathrm{H}^{+}\right)$:434.32648; Found:434.32578.

\section{2- $\mathrm{N}$-iso-butylpleuromutilin (9)}

Prepared according to the above general preparation of pleutromutilin derivatives 8-11. White powder; yield: $62.0 \%$; m.p.: $130.0-130.8^{\circ} \mathrm{C} ;{ }^{1} \mathrm{H}-\mathrm{NMR}$ spectrum (600 MHz; $\mathrm{d}_{1}-\mathrm{CDCl}_{3}$. TMS): $\delta(\mathrm{ppm}) 6.523(1 \mathrm{H}, \mathrm{dd}, J 11.4,17.4$, $\mathrm{H} 19), 5.794(1 \mathrm{H}, \mathrm{d}, J 8.4, \mathrm{H} 14), 5.354(1 \mathrm{H}, \mathrm{dd}, J 1.2,10.8, \mathrm{H} 20), 5.203(1 \mathrm{H}$ dd, $J 1.2,17.4, \mathrm{H} 20), 3.371-3.324(2 \mathrm{H}, \mathrm{m}, \mathrm{H} 22), 3.245(1 \mathrm{H}, \mathrm{d}, J 17.4, \mathrm{H} 11)$, $2.437-2.054\left(7 \mathrm{H}, \mathrm{m}, \mathrm{H} 2, \mathrm{H} 4, \mathrm{H} 10, \mathrm{H} 13,\left(\mathrm{CH}_{3}\right)_{2} \mathrm{CHCH}_{2} \mathrm{NH}\right), 1.789-1.597$ $(6 \mathrm{H}, \mathrm{m}, \mathrm{H1}, \mathrm{H} 6, \mathrm{H} 7,11-\mathrm{OH}), 1.579-1.529(1 \mathrm{H}, \mathrm{m}, \mathrm{H} 8), 1.476-1.456(1 \mathrm{H}, \mathrm{m}$, $\left.\left(\mathrm{CH}_{3}\right)_{2} \mathrm{CHCH}_{2} \mathrm{NH}\right) 1.448(3 \mathrm{H}, \mathrm{s}, \mathrm{H} 15), 1.390-1.341(1 \mathrm{H}, \mathrm{m}, \mathrm{H} 8) 1.306(1 \mathrm{H}, \mathrm{d}$, $J 16.2, \mathrm{H} 13), 1.165(3 \mathrm{H}, \mathrm{s}, \mathrm{H} 18), 0.909\left(6 \mathrm{H}, \mathrm{dd}, J 1.8,2.4,\left(\mathrm{CH}_{3}\right)_{2} \mathrm{CHCH}_{2} \mathrm{NH}\right)$, $0.878(3 \mathrm{H}, \mathrm{d}, J 6.6, \mathrm{H} 17), 0.723(3 \mathrm{H}, \mathrm{d}, J 7.2, \mathrm{H} 16)$; IR $\left(\mathrm{KBr}, \mathrm{cm}^{-1}\right) 3448.52$, 2954.54, 2870.12, 1727.50, 1637.61, 1459.23, 1150.84, 1115.58, 1017.46; HRMS (ESI): Calcd for $\mathrm{C}_{26} \mathrm{H}_{44} \mathrm{NO}_{4}\left(\mathrm{M}-\mathrm{H}^{+}\right): 434.32648$; Found:434.32605.

22- $\mathrm{N}$-sec-butylpleuromutilin (10)

Prepared according to the above general preparation of pleutromutilin derivatives 8-11. White powder; yield: $53.1 \%$; m.p.: $107.5-109.3^{\circ} \mathrm{C}$; ${ }^{1} \mathrm{H}-\mathrm{NMR}$ spectrum (600 MHz; $\left.\mathrm{d}_{1}-\mathrm{CDCl}_{3:} \mathrm{TMS}\right): \delta(\mathrm{ppm}) 6.532-6.478(1 \mathrm{H}, \mathrm{m}, \mathrm{H} 19)$, 5.806-5.759 $(1 \mathrm{H}, \mathrm{m}, \mathrm{H} 14), 5.354-5.318(1 \mathrm{H}, \mathrm{m}, \mathrm{H} 20), 5.216-5.170(1 \mathrm{H}, \mathrm{m}$ $\mathrm{H} 20), 3.454-3.316$ (3H, m, H11, H22), $2.628(1 \mathrm{H}$, br s, 11-OH), 2.377-2.034 $\left(6 \mathrm{H}, \mathrm{m}, \mathrm{H} 2, \mathrm{H} 4, \mathrm{H} 10, \mathrm{H} 13, \mathrm{CH}_{3} \mathrm{CH}_{2} \mathrm{CH}\left(\mathrm{CH}_{3}\right) \mathrm{NH}\right), 1.775(1 \mathrm{H}, \mathrm{dd}, J 3.0,14.4$, $\mathrm{H} 8), 1.686-1.464(5 \mathrm{H}, \mathrm{m}, \mathrm{H} 1, \mathrm{H} 6, \mathrm{H} 7), 1.451(3 \mathrm{H}, \mathrm{s}, \mathrm{H} 15), 1.438-1.303(4 \mathrm{H}$, $\left.\mathrm{m}, \mathrm{H} 8, \mathrm{H} 13, \mathrm{CH}_{3} \mathrm{CH}_{2} \mathrm{CH}\left(\mathrm{CH}_{3}\right) \mathrm{NH}\right), 1.165(3 \mathrm{H}, \mathrm{d}, \mathrm{J} 2.4, \mathrm{H} 18), 1.050(3 \mathrm{H}, \mathrm{dd}$, $J$ 6.0, 6.6, $\left.\mathrm{CH}_{3} \mathrm{CH}_{2} \mathrm{CH}\left(\mathrm{CH}_{3}\right) \mathrm{NH}\right), 0.925-0.845\left(6 \mathrm{H}, \mathrm{m}, \mathrm{H} 17, \mathrm{CH}_{3} \mathrm{CH}_{2} \mathrm{CH}\left(\mathrm{CH}_{3}\right)\right.$ $\mathrm{NH}), 0.706(3 \mathrm{H}, \mathrm{dd}, J 7.2, \mathrm{H} 16)$; IR $\left(\mathrm{KBr}, \mathrm{cm}^{-1}\right) 3452,182957.82,1735.34$,
1637.92, 1464.54, 1154.54, 1116.74, 1037.83; HR-MS (ESI): Calcd for $\mathrm{C}_{26} \mathrm{H}_{44} \mathrm{NO}_{4}\left(\mathrm{M}-\mathrm{H}^{+}\right): 434.32648$; Found:434.32648.

\section{2-N-tert-butylpleuromutilin (11)}

Prepared according to the above general preparation of pleutromutilin derivatives 8-11. White powder; yield: $44.3 \%$; m.p.: $174.7-176.4^{\circ} \mathrm{C}$; ${ }^{1} \mathrm{H}-\mathrm{NMR}$ spectrum $\left(600 \mathrm{MHz} ; \mathrm{d}_{1}-\mathrm{CDCl}_{3}\right.$. TMS): $\delta(\mathrm{ppm}) 6.513(1 \mathrm{H}, \mathrm{dd}, J 10.8,17.4$, H19), $5.776(1 \mathrm{H}, \mathrm{d}, J 8.4, \mathrm{H} 14), 5.341(1 \mathrm{H}, \mathrm{d}, J 11.4, \mathrm{H} 20), 5.195(1 \mathrm{H}, \mathrm{dd}, J$ $17.4, \mathrm{H} 20), 3.389-3.315(2 \mathrm{H}, \mathrm{m}, \mathrm{H} 22), 3.262(1 \mathrm{H}, \mathrm{d}, J 17.4, \mathrm{H} 11), 2.366-2.041$ (5H, m, H2, H4, H10, H13), 1.785-1.756 (1H, m, H8), 1.684-1.440 (6H, m, H1, H6, H7, 11-OH), $1.454(3 \mathrm{H}, \mathrm{s}, \mathrm{H} 15), 1.383-1.348(1 \mathrm{H}, \mathrm{m}, \mathrm{H} 8), 1.323(1 \mathrm{H}, \mathrm{d}, J$ 16.2, H13), 1.159 (3H, s, H18), $1.083\left(9 \mathrm{H}, \mathrm{s},\left(\mathrm{CH}_{3}\right)_{3} \mathrm{NH}\right), 0.877(3 \mathrm{H}, \mathrm{d}, J 6.6$, H17), 0.717 (3H, d, J 7.2, H16); IR (KBr, $\left.\mathrm{cm}^{-1}\right) 3316.59,2935.51,2882.35$, 1736.63, 1641.43, 1467.34, 1153.12, 1118.63, 1016.50; HR-MS (ESI): Calcd for $\mathrm{C}_{26} \mathrm{H}_{44} \mathrm{NO}_{4}\left(\mathrm{M}-\mathrm{H}^{+}\right): 434.32648$; Found:434.32626.

\section{Minimal inhibitory concentration (MIC) testing}

MIC values of 4 novel pleuromutilin derivatives, tiamulin, valnemulin and pleuromutilin were determined by agar dilution in accordance with the "Clinical and Laboratory Standards Institute" (CLSI, 2008). ${ }^{15}$ The following reference strains were used for quality control: Streptococcus agalactiae CVCC 586, Streptococcus pyogenes CVCC 593, Enterococcus faecalis ATCC 29212, Escherichia coli ATCC 25922, Staphylococcus aureus ATCC 29213.

Preparation of stock and working solutions of compounds 8-11

Stock solutions of compounds 8-11 were prepared in N,NDimethylformamide (DMF) at the concentrations of $5120 \mu \mathrm{g} / \mathrm{ml}$. The working solutions $(256 \mu \mathrm{g} / \mathrm{ml})$ were obtained by diluting stock solutions in sterile Mueller Hinton broth.

\section{Preparation of bacteria solution}

After all five strains were all recovered, single colony selected was inculated on Mueller Hinton agar respectively, follow by incubation for 18$24 \mathrm{~h}$ at $37^{\circ} \mathrm{C}$. Then, inocula were prepared by transferring several colonies of bacteria to saline. The suspensions were mixed for $15 \mathrm{~s}$ and then corrected to $0.5 \mathrm{McF}$ arland standard using saline. Further dilutions in saline were made to get the required working suspensions $\left(10^{5} \mathrm{CFU} / \mathrm{ml}\right)$

\section{The determination of MIC}

The test was performed in 96-well plate. All dates were tested in duplicate in each plate. $100 \mu \mathrm{l}$ of Mueller Hinton broth was added into all the wells of the 96-well plate. $100 \mu \mathrm{l}$ of the working solutions $(256 \mu \mathrm{g} / \mathrm{ml})$ of compounds 8-11 were added into the wells in rows A to $\mathrm{H}$ in column 1 and well mixed. Then $100 \mu 1$ of the mixture in column 1 was inhaled to add into the wells in column 2 , well mixed. The similar operation was repeated until the 10th row of wells was filled. $100 \mu 1$ of excess medium was discarded from the wells in column 10. $100 \mu \mathrm{l}$ of the bacteria solution was added to the wells in rows $\mathrm{A}$ to $\mathrm{H}$ in columns 1 to 10 , well mixed.

Two columns served as drug-free controls (no cultures were added in one column and drugs replaced by blank solvent in the other column). Tiamulin and Valnemulin were used as positive controls against bacteria. The final concentration of DMF in the first well column was $1.25 \%$. Initially, preliminary analyses were conducted with $1.25 \%(\mathrm{v} / \mathrm{v}) \mathrm{DMF} / \mathrm{MHB}$ and this did not affect neither the growth of the tested bacteria nor the determination of MIC. The concentration of drugs in each row of well were $64,32,16,8,4,2,1,0.5,0.25$, $0.125 \mu \mathrm{g} / \mathrm{ml}$ respectively. Each 96 -well plate was covered and incubated for $18-24 \mathrm{~h}$ at $37^{\circ} \mathrm{C}$. The MIC value was defined as the lowest concentration of the sample which inhibits the visible growth of test bacteria.

\section{RESULTS}

\section{Synthesis}

The structural modification of pleuromutilin focused on variations of the C-14 side-chain. Previous to this research, tiamulin and valnemulin were successfully developed for veterinary use; retapamulin was successfully approved for use in human skin infections. ${ }^{16,17}$ The success of these three drugs showed that pleuromutilin derivatives with different $\mathrm{C}-14$ side-chain might yield other candidates suitable for developing new antibacterial drugs in the future. The steric configuration of the $\mathrm{C}-14$ side-chain of pleuromutilin derivatives might influence their antibacterial activities. In order to clarify this influence, four pleuromutilin derivatives which have $n$-butyl, iso-butyl, sec-butyl and tert-butyl groups in their $\mathrm{C}$-14 side-chain were designed and synthesized (8-11). The results showed that the compound having a tert-butyl amine side chain possessed less antibacterial activity against Staphylococcus aureus than the other derivatives.

Reaction of pleuromutilin (1) with $p$-toluenesulfonyl chloride in pyridine at $0^{\circ} \mathrm{C}$ gave compound 1a. The compounds 8-11 were prepared via four amines according to the method described in the literature for pleuromutilin 
derivatives, with slightly modification. ${ }^{18}$ Treatment of butyl amine in acetonitrile followed by nucleophilic substitution reaction with compound $1 \mathrm{a}$ at $80^{\circ} \mathrm{C}$ for 4 hours led to the desired compounds 8-11. Finally, the pure products could be obtained in good yield (53.1\% for n-butyl amine, $62.0 \%$ for iso-butyl amine, 53.1 $\%$ for sec-butyl amine and $44.3 \%$ for tert-butyl amine) by silica gel column chromatography using petroleum ether/ethyl acetate/ethanol (5:1:0.2) as eluent. The chemical structures of compounds 8-11 were confirmed by FT-IR, ${ }^{1} \mathrm{H}-\mathrm{NMR}$, and HR-MS.

MIC testing

The in vitro antibacterial activity of compounds 8-11, pleuromutilin, tiamulin and valnemulin were tested. Their MIC values against five tested bacteria were showed in Table 1.

Table 1. The MIC values of compounds $8 \sim 11$, pleuromutilin, tiamulin and valnemulin against five tested bacteria $\left(\mu \mathrm{g} \mathrm{mL} \mathrm{m}^{-1}\right)$

\begin{tabular}{|c|c|c|c|c|c|}
\hline \multirow{2}{*}{ Compound } & \multicolumn{5}{|c|}{ MIC values $/\left(\mu \mathrm{g} \mathrm{\textrm {mL } ^ { - 1 } )}\right.$} \\
\cline { 2 - 6 } & $\begin{array}{c}\text { S. agalactiae CVCC } \\
586\end{array}$ & $\begin{array}{c}\text { S. pyogenes } \\
\text { CVCC } 593\end{array}$ & $\begin{array}{c}\text { E. faecalis ATCC } \\
29212\end{array}$ & $\begin{array}{c}\text { E. coli ATCC } \\
25922\end{array}$ & $\begin{array}{c}\text { S. aureus ATCC } \\
29213\end{array}$ \\
\hline $\mathbf{8}$ & $>64$ & $>64$ & $>64$ & $>64$ & 4 \\
\hline $\mathbf{9}$ & $>64$ & $>64$ & $>64$ & $>64$ & 2 \\
\hline $\mathbf{1 0}$ & 32 & 32 & 32 & $>32$ & 32 \\
\hline $\mathbf{1 1}$ & $>64$ & $>64$ & $>64$ & 32 & 0.5 \\
\hline $\mathbf{1}$ & 32 & 32 & 32 & 32 & 0.125 \\
\hline $\mathbf{2}$ & 64 & $>64$ & 64 & 16 & $>0.125$ \\
\hline $\mathbf{3}$ & 32 & 64 & 16 & & 32 \\
\hline
\end{tabular}

\section{DISCUSSION}

All four target compounds showed some antibacterial activity against all five tested bacteria. The MIC values of compounds 8-11 against Staphylococcus aureus ATCC 29213 were $4 \mu \mathrm{g} \mathrm{mL}^{-1}, 2 \mu \mathrm{g} \mathrm{mL}^{-1}, 4 \mu \mathrm{g} \mathrm{mL}^{-1}$ and $32 \mu \mathrm{g} \mathrm{mL}$ ${ }^{1}$, respectively. The pleuromutilin derivatives selectively inhibit bacterial protein synthesis through their interaction with prokaryotic ribosome. The C-14 side-chain extension of pleuromutilin derivatives is likely to enhance their antimicrobial activity through strengthening the interaction between pleuromutilin derivatives and ribosomal peptidyl transferase in bacteria. ${ }^{19}$ Considering our current results, it is proposed that the steric hindrance of tertbutyl impedes the interaction between compound $\mathbf{1 1}$ and the ribosomal peptidyl transferase of Staphylococcus aureus ATCC 29213, and then decreases the antibacterial activity of compound $\mathbf{1 1}$.

The antibacterial activity of compounds 8-10 against Staphylococcus aureus ATCC 29213 were much higher than the antibacterial activity of them against the other four tested bacteria. It is supposed that the different antibacterial activity of the same compound is caused by the difference of the ribosome of the five tested bacterial. For example, the interaction between compound $\mathbf{8}$ and the ribosomal peptidyl transferase of Staphylococcus aureus ATCC 29213 is mode A (Figure 3), while the interaction between this compound and the ribosomal peptidyl transferase of Escherichia coli ATCC 25922 is mode B (Figure 3). Such different mode of interaction might be the reason of differential activity of compound $\mathbf{8}$ against these two bacteria. ${ }^{12,20}$

\section{CONCLUSION}

Four pleuromutilin derivatives were designed, synthesized and identified in this paper. The MIC values of compound $\mathbf{8}, \mathbf{1 0}$ against Staphylococcus aureus ATCC 29213 were $4 \mu \mathrm{g} \mathrm{mL}^{-1}$. The MIC value of compound 9 was 2 $\mu \mathrm{g} \mathrm{mL}^{-1}$ for Staphylococcus aureus ATCC 29213, while that of compound 11 reached $32 \mu \mathrm{g} \mathrm{mL}^{-1}$. Antibacterial activity of pleuromutilin derivatives could be affected by the steric hindrance of their C-14 side-chain. In addition, the MIC values of compound $\mathbf{1 0}$ against other four tested bacterial reached $32 \mu \mathrm{g}$ $\mathrm{mL}^{-1}$, while that of compounds $\mathbf{8}, \mathbf{9}$ and $\mathbf{1 1}$ were greater than $64 \mu \mathrm{g} \mathrm{mL}^{-1}$. Thus, pleuromutilin derivatives with short $\mathrm{C}-14$ side-chain might not be good choice for developing new antibacterial drugs against these four tested bacterial in this paper. Our results could be used to enrich the content of SAR of pleuromutilin and promote rational design of novel potent pleuromutilin-based antibiotic.
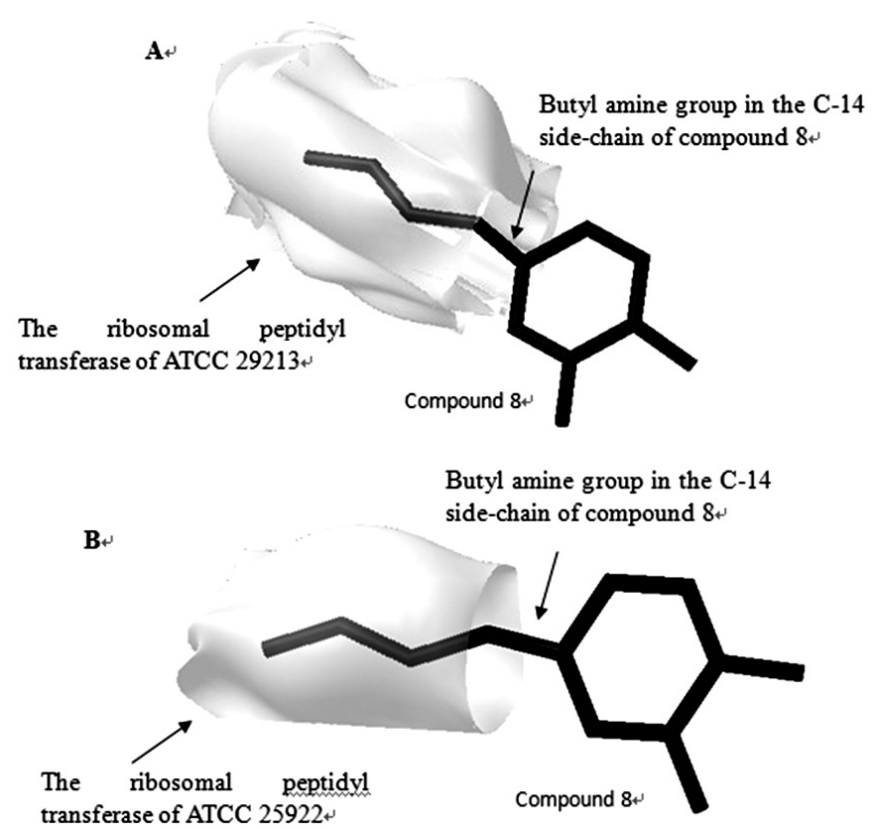

Figure 3. Supposed interaction between compound $\mathbf{8}$ and the ribosome of bacterial. A: Interaction between compound $\mathbf{8}$ and the ribosome of Staphylococcus aureus ATCC 29213; B: Interaction between compound 8 and the ribosome of Escherichia coli ATCC 25922

\section{ACKNOWLEDGMENTS}

This work was supported by Program Foundation for Distinguished Young Talents in Higher Education of Guangdong, China (No. LYM09032), National Natural Science Foundation of China (No. 31001085), Foundation of President of South China Agricultural University (No. 5500-K11046), The undergraduate innovative experiment project of Guangdong Province (No. SCAU109).

\section{REFERENCES}

1. R. Novak, Ann. N. Y. Acad. Sci. 1241, 71, (2011)

2. M. S. Butler, A. D. Buss, Biochem. Pharmacol. 71, 919, (2006)

3. B. Boyd, J. Castaner, Drugs Future 31, 107, (2006) 
4. F. Kavanagh, A. Hervey, W. J. Robbins, Proc. Natl. Acad. Sci. U. S. A. 37, $570,(1951)$

5. L. Lolk, J. Pohlsgaard, A. S. Jepsen, L. H. Hansen, H. Nielsen, S. I Steffansen, L. Sparving, A. B. Nielsen, B. Vester, P. Nielsen, J. Med. Chem. 51, 4957, (2008)

6. G. Brooks, W. Burgess, D. Colthurst, J. D. Hinks, E. Hunt, M. J. Pearson, B. Shea, A. K. Takle, J. M. Wilson, G. Woodnutt, Bioorg. Med. Chem. 9, 1221, (2001)

7. J. Liu, S. D. Lotesta, E. J. Sorensen, Chem. Commun. 47, 1500, (2011)

8. S. D. Lotesta, J. Liu, E. V. Yates, I. Krieger, J. C. Sacchettini, J. S. Freundlich, E. Sorensen, J. Chem. Sci. 2, 1258, (2011)

9. T. J. K. Findley, D. Sucunza, L. C. Miller, M. D. Helm, M. Helliwell, D. T. Davies, D. J. Procter, Org. Biomol. Chem. 9, 2433, (2011)

10. O. A. Phillips, L. H. Sharaf, Expert Opin. Ther. Pat. 17, 429, (2007)

11. E. Hunt, Drugs Future 25, 1163, (2000)
12. C. Davidovich, A. Bashan, T. Auerbach-Nevo, R. D. Yaggie, R. R. Gontarek, A. Yonath, Proc. Natl. Acad. Sci. U. S. A. 104, 4291, (2007)

13. Y. Hirokawa, H. Kinoshita, T. Tanaka, T. Nakamura, K. Fujimoto, S. Kashimoto, T. Kojima, S. Kato, Bioorg. Med. Chem. Lett. 18, 3556, (2008)

14. Y. Hirokawa, H. Kinoshita, T. Tanaka, T. Nakamura, K. Fujimoto, S. Kashimoto, T. Kojima, S. Kato, Bioorg. Med. Chem. Lett. 19, 170, (2009)

15. Institute, C. A. L. S. (2008)

16. N. Rodger, S. D. M, Curr. Opin. Invest. Drugs 11, 182, (2010)

17. Y. Z. Tang, Y. H. Liu, J. X. Chen, Mini-Rev. Med. Chem. 12, 53, (2012)

18. P. Xu, Y. Zhang, Y. Sun, J. Liu, B. Yang, Y. Wang, Y. Wang, Chem. Biol. Drug Des. 73, 655, (2009)

19. K. S. Long, L. H. Hansen, L. Jakobsen, B. Vester, Antimicrob. Agents Chemother. 50, 1458, (2006)

20. G. Hogenauer, C. Ruf, Antimicrob. Agents Chemother. 19, 260, (1981) 